\title{
Effect of Different Nitrogen and Phosphorus Levels on Growth and Yield of Maize during Kharif Season
}

\author{
U. Vijaya Bhaskar Reddy*, G. Prabhakara Reddy, M. Srinivasa Reddy and P. Kavitha \\ S.V. Agricultural College, Tirupati, Acharya N.G. Ranga Agricultural University, India \\ *Corresponding author
}

\section{A B S T R A C T}

\begin{tabular}{|l|}
\hline Ke y w ord s \\
Maize, Nitrogen, \\
Phosphorus, \\
Growth parameters \\
\hline Article Info \\
\hline $\begin{array}{l}\text { Accepted: } \\
\text { 26 October } 2017 \\
\text { Available Online: } \\
\text { 10 January } 2018\end{array}$ \\
\hline
\end{tabular}

Keywords

Maize, Nitrogen,

Phosphorus,

Growth parameters

Article Info

Accepted:

vailable Online:

\section{Introduction}

Wheat, rice and maize are the most important cereal crops in the world but maize is the most popular due to its high yielding, ease of processing, readily digested and costs less than other cereals (Jaliya et al., 2008). Maize as a major source of carbohydrate is used as food, in livestock diet and in alcohol production. Maize has immense potential in the tropics and yield of up to $7500 \mathrm{~kg} \mathrm{ha}^{-1}$ can be obtained if the crop is properly managed. Unfortunately, yields are still generally below $5000 \mathrm{~kg} \mathrm{ha}^{-1}$ (FAO, 2007) and this had caused inadequacy of maize for its numerous usages. Yield differences between temperate and tropical areas have been attributed to low nutrient status of tropical soils especially nitrogen, phosphorus and potassium resulting from the practice of slash and burn farming system with excessive leaching of the soil nutrients. The low fertility status of most tropical soils hindered maize production as maize has a strong exhausting effect on the soil. Luxuriant growth resulting from fertilizer application leads to larger dry matter production owing to better utilization of solar radiation and nutrients (Saeed et al., 2001). Conflicting results about the benefits and adverse effects of fertilizer have however been found in literature. Ayoola and Adeniyan (2006) had reported that the use of inorganic fertilizer has not been helpful under intensive agriculture because it is often associated with reduced yield, nutrient imbalance, leaching and pollution of 
groundwater. In view of inconsistency in the fertilizer and increasing cost of production associated with its usage, field trials were conducted in 2014 and 2015 to determine the appropriate $\mathrm{N}$ and $\mathrm{P}$ rate that will produce the optimum yield in maize.

\section{Materials and Methods}

Field trial was conducted at College Farm of Agricultural College, Mahanandi campus of Acharya N. G. Ranga Agricultural University, situated at $15.51^{\circ} \mathrm{N}$ latitude, $78.61^{\circ} \mathrm{E}$ longitude and at an altitude of $233.5 \mathrm{~m}$ above the mean sea level, in the Scarce Rainfall Zone of Andhra Pradesh during kharif seasons of 2014 and 2015. The soil was sandy loam in texture, neutral in reaction $(\mathrm{pH}$ of 7.34), low in organic carbon $(0.45 \%)$ and available nitrogen $\left(275 \mathrm{~kg} \mathrm{ha}^{-1}\right)$, medium in available phosphorus (153 kg ha $\left.{ }^{-1}\right)$ and high in available potassium( $\left.670 \mathrm{~kg} \mathrm{ha}^{-1}\right)$, during beginning of experimentation.

The trials were laid down in a randomized block design with factorial concept. The treatments included three nitrogen levels (200 $\mathrm{kg} \mathrm{ha}^{-1}\left(\mathrm{~N}_{1}\right), 250 \mathrm{~kg} \mathrm{ha}^{-1}\left(\mathrm{~N}_{2}\right)$ and $300 \mathrm{~kg} \mathrm{ha}^{-1}$ $\left.\left(\mathrm{N}_{3}\right)\right)$ and three phosphorus levels $\left(40 \mathrm{~kg} \mathrm{ha}^{-1}\right.$ $\left(\mathrm{P}_{1}\right), 60 \mathrm{~kg} \mathrm{ha}^{-1}\left(\mathrm{P}_{2}\right)$ and $\left.80 \mathrm{~kg} \mathrm{ha}^{-1}\left(\mathrm{P}_{3}\right)\right)$. The test variety of maize was P-3396 a single cross hybrid. Recommended practices for disease and insect pest control were followed. Nitrogen was applied at graded levels as per the treatments in three splits i.e., one third at basal, one third at knee high stage and the remaining one third at tasseling stage. Entire quantity of $\mathrm{P}_{2} \mathrm{O}_{5}$ as per the treatments and $\mathrm{K}_{2} \mathrm{O}\left(60 \mathrm{~kg} \mathrm{~K}_{2} \mathrm{O} \mathrm{ha}^{-1}\right)$ was applied as a basal dose. The sources of nitrogen, phosphorus and potassium were urea, single super phosphate and muriate of potash respectively. The split dose of nitrogen fertilizer was applied by placement at $5 \mathrm{~cm}$ away and $5 \mathrm{~cm}$ below the seed rows. Five plants were randomly selected per plot for determination of growth parameters. The growth parameters assessed included plant height $(\mathrm{cm})$, leaf area index (LAI) and total dry matter $\left(\mathrm{kg} \mathrm{ha}^{-1}\right)$. At harvest, the cobs and stover were harvested and weighed separately. The cobs and stover were dried and re-weighed. The grain on the cobs were shelled and weighed.

The data recorded on hybrid maize for various parameters during the course of investigation were statistically analyzed following the method of analysis of variance for randomized block design with factorial concept. Wherever the treatmental differences were found significant (' $F$ ' test), critical difference was worked out at $0.05 \%$ probability level and the values are furnished. Treatmental differences that were nonsignificant are denoted as NS.

\section{Results and Discussion}

\section{Plant height}

Among the nitrogen levels, application of nitrogen at $300 \mathrm{~kg} \mathrm{ha}^{-1}\left(\mathrm{~N}_{3}\right)$ produced taller plants, which were on par with that of $250 \mathrm{~kg}$ $\mathrm{N} \mathrm{ha}{ }^{-1}\left(\mathrm{~N}_{2}\right)$ at all the stages of crop growth except at 30 DAS during the first year (Table. 1). Improvement in plant height with each successive increment of nitrogen might be attributed to the fact that nitrogen is an integral part of proteins, the building blocks of plant and it also helps in maintaining higher auxin level which might have resulted in better plant height. Similar findings were reported by Dawadi and Sah (2012) and Nsanzabaganwa et al., (2014).

Among the phosphorus levels, application of $60 \mathrm{~kg} \mathrm{P}_{2} \mathrm{O}_{5} \mathrm{ha}^{-1}\left(\mathrm{P}_{2}\right)$ produced taller plants in the first year and $80 \mathrm{~kg} \mathrm{P}_{2} \mathrm{O}_{5} \mathrm{ha}^{-1}\left(\mathrm{P}_{3}\right)$ in the second year. Improvement in plant height with higher phosphorus levels over and above $40 \mathrm{~kg} \mathrm{P}_{2} \mathrm{O}_{5}$ ha $^{-1}\left(\mathrm{P}_{2}\right)$ might be attributed to the fact that phosphorus is a constituent of nucleic 
acids, phospholipids, coenzymes and most importantly ATP. It activates coenzymes for amino acid production used in protein synthesis which might have resulted in better plant height. Similar results were obtained by Gemechu (2011).

With regard to interaction, increase in levels of nitrogen in combination with increased phosphorus levels resulted in taller plants i.e $\mathrm{N}_{3} \mathrm{P}_{3}\left(300 \mathrm{~kg} \mathrm{~N}+80 \mathrm{~kg} \mathrm{P}_{2} \mathrm{O}_{5} \mathrm{ha}^{-1}\right)$ at $30 \mathrm{DAS}$ and $\mathrm{N}_{2} \mathrm{P}_{2}\left(250 \mathrm{~kg} \mathrm{~N}+60 \mathrm{~kg} \mathrm{P}_{2} \mathrm{O}_{5} \mathrm{ha}^{-1}\right)$ at 90 DAS. The increase in plant height in the presence of adequate nutrients might be due to rapid cell division and cell elongation which might have stimulated the growth. Significant interaction between nitrogen and phosphorus levels with respect to plant height was in conformity with the works of Baffoe (2014).

\section{Leaf Area Index}

Significantly higher LAI was recorded with the application of $300 \mathrm{~kg} \mathrm{~N}^{-1}\left(\mathrm{~N}_{3}\right)$ followed by $250 \mathrm{~kg} \mathrm{~N} \mathrm{ha}^{-1}\left(\mathrm{~N}_{2}\right)$, whereas the lowest
LAI was obtained with $200 \mathrm{~kg} \mathrm{~N} \mathrm{ha}{ }^{-1}\left(\mathrm{~N}_{1}\right)$ (Table. 2). Increase in LAI with application of nitrogen at higher levels might be due to adequate dose and timely application which could have facilitated luxurious uptake of nitrogen, triggering the foliage emergence. The positive effect of nitrogen on LAI in terms of more leaf elongation and less leaf senescence leading to production of larger leaves and improved photosynthetic capacity of the plants was also quoted by Nsanzabaganwa et al., (2014) and Thimmappa et al., (2014).

With regard to phosphorus, application of 60 $\mathrm{kg} \mathrm{ha}^{-1}\left(\mathrm{P}_{2}\right)$ resulted in higher LAI, which was comparable to $80 \mathrm{~kg} \mathrm{ha}^{-1}\left(\mathrm{P}_{3}\right)$ and was significantly superior to $40 \mathrm{~kg} \mathrm{ha}^{-1}\left(\mathrm{P}_{1}\right)$. This was due to availability of adequate phosphorus at higher levels of application which encouraged leaf expansion and growth. Similar observations were also recorded by Gemechu (2011) and Araei and Mojaddam (2014). The interaction was not significant with respect to LAI during both the years of study.

\begin{tabular}{|c|c|c|c|c|c|c|c|c|}
\hline \multicolumn{9}{|c|}{ Table.1 Plant height $(\mathrm{cm})$ of maize at different growth stages during kharif season } \\
\hline \multirow{3}{*}{ Treatments } & \multicolumn{8}{|c|}{ Plant height } \\
\hline & \multicolumn{2}{|c|}{$30 \mathrm{DAS}$} & \multicolumn{2}{|c|}{$60 \mathrm{DAS}$} & \multicolumn{2}{|c|}{$90 \mathrm{DAS}$} & \multicolumn{2}{|c|}{ At Harvest } \\
\hline & 2014 & 2015 & 2014 & 2015 & 2014 & 2015 & 2014 & 2015 \\
\hline \multicolumn{9}{|c|}{ Nitrogen levels $\left(\mathrm{kg} \mathrm{N} \mathrm{ha}^{-1}\right)$} \\
\hline $\mathbf{N}_{1}$ & 106.2 & 94.5 & 268.8 & 257.6 & 276.2 & 269.2 & 276.8 & 269.4 \\
\hline $\mathbf{N}_{2}$ & 111.8 & 96.4 & 269.9 & 260.9 & 277.7 & 272.0 & 277.8 & 272.4 \\
\hline $\mathbf{N}_{3}$ & 117.9 & 99.1 & 274.1 & 261.2 & 281.6 & 271.7 & 281.6 & 273.5 \\
\hline SEm \pm & 1.10 & 1.56 & 2.16 & 2.83 & 1.69 & 3.71 & 2.34 & 4.21 \\
\hline $\mathrm{CD}(\mathrm{P}=0.05)$ & 3.30 & NS & NS & NS & 5.1 & NS & NS & NS \\
\hline \multicolumn{9}{|c|}{ Phosphorus levels $\left(\mathrm{kg} \mathrm{P}_{2} \mathrm{O}_{5} \mathrm{ha}^{-1}\right)$} \\
\hline $\mathbf{P}_{1}$ & 108.6 & 95.8 & 270.4 & 257.6 & 273.6 & 271.7 & 276.0 & 271.9 \\
\hline $\mathbf{P}_{2}$ & 115.9 & 97.3 & 271.6 & 263.2 & 279.7 & 268.4 & 279.9 & 269.9 \\
\hline $\mathbf{P}_{3}$ & 111.4 & 96.9 & 270.5 & 259.0 & 279.0 & 272.9 & 279.4 & 274.6 \\
\hline SEm \pm & 1.10 & 1.56 & 2.16 & 2.83 & 1.69 & 3.71 & 2.34 & 4.21 \\
\hline $\mathrm{CD}(\mathbf{P}=\mathbf{0 . 0 5})$ & 3.30 & NS & NS & NS & 5.1 & NS & NS & NS \\
\hline \multicolumn{9}{|l|}{ Interaction } \\
\hline SEm \pm & 1.91 & 2.70 & 3.73 & 4.91 & 2.94 & 6.43 & 4.05 & 7.30 \\
\hline $\mathrm{CD}(\mathrm{P}=\mathbf{0 . 0 5})$ & 5.72 & $\mathrm{NS}$ & NS & NS & 8.8 & NS & NS & NS \\
\hline
\end{tabular}


Interaction between $N$ and $P$ levels on plant height of maize at 30 DAS during 2014

\begin{tabular}{|c|c|c|c|c|}
\hline & $\mathbf{P}_{\mathbf{1}}$ & $\mathbf{P}_{\mathbf{2}}$ & $\mathbf{P}_{\mathbf{3}}$ & Mean \\
\hline $\mathbf{N}_{\mathbf{1}}$ & 105.7 & 108.4 & 104.3 & 106.2 \\
\hline $\mathbf{N}_{\mathbf{2}}$ & 110.5 & 118.5 & 106.4 & 111.8 \\
\hline $\mathbf{N}_{\mathbf{3}}$ & 109.5 & 120.9 & 123.3 & 117.9 \\
\hline Mean & 108.6 & 115.9 & 111.4 & \\
\hline
\end{tabular}

Interaction between $\mathrm{N}$ and $\mathrm{P}$ levels on plant height of maize at 90 DAS during 2014

\begin{tabular}{|c|c|c|c|c|}
\hline & $\mathbf{P}_{\mathbf{1}}$ & $\mathbf{P}_{\mathbf{2}}$ & $\mathbf{P}_{\mathbf{3}}$ & Mean \\
\hline $\mathbf{N}_{\mathbf{1}}$ & 269.9 & 279.8 & 278.8 & 276.2 \\
\hline $\mathbf{N}_{\mathbf{2}}$ & 273.9 & 283.1 & 277.2 & 277.7 \\
\hline $\mathbf{N}_{\mathbf{3}}$ & 280.9 & 282.8 & 281.1 & 281.6 \\
\hline Mean & 274.9 & 281.9 & 279.0 & \\
\hline
\end{tabular}

Table.2 Leaf area index of maize at different growth stages during kharif season

\begin{tabular}{|c|c|c|c|c|c|c|c|c|}
\hline \multirow{3}{*}{ Treatments } & \multicolumn{8}{|c|}{ Leaf area index } \\
\hline & \multicolumn{2}{|c|}{30 DAS } & \multicolumn{2}{|c|}{$60 \mathrm{DAS}$} & \multicolumn{2}{|c|}{$90 \mathrm{DAS}$} & \multicolumn{2}{|c|}{ At Harvest } \\
\hline & 2014 & 2015 & 2014 & 2015 & 2014 & 2015 & 2014 & 2015 \\
\hline \multicolumn{9}{|c|}{ Nitrogen levels $\left(\mathrm{kg} \mathrm{N} \mathrm{ha}^{-1}\right)$} \\
\hline$\overline{N_{1}}$ & 2.26 & 1.38 & 4.26 & 4.33 & 4.27 & 4.36 & 4.26 & 3.12 \\
\hline $\mathbf{N}_{2}$ & 2.36 & 1.63 & 4.65 & 4.42 & 4.75 & 4.65 & 4.64 & 3.22 \\
\hline $\mathbf{N}_{3}$ & 2.47 & 1.89 & 4.80 & 4.45 & 5.08 & 4.75 & 5.03 & 3.24 \\
\hline SEm \pm & 0.08 & 0.24 & 0.234 & 0.212 & 0.205 & 0.119 & 0.195 & 0.127 \\
\hline $\begin{array}{l}\mathrm{CD}(\mathrm{P}= \\
0.05 \%)\end{array}$ & NS & NS & NS & NS & 0.51 & 0.35 & 0.58 & NS \\
\hline \multicolumn{9}{|c|}{ Phosphorus levels $\left(\mathrm{kg} \mathrm{P}_{2} \mathrm{O}_{5} \mathrm{ha}^{-1}\right)$} \\
\hline $\mathbf{P}_{1}$ & 2.31 & 1.59 & 4.01 & 4.05 & 4.10 & 4.32 & 4.02 & 3.16 \\
\hline $\mathbf{P}_{2}$ & 2.42 & 1.68 & 4.56 & 4.46 & 4.76 & 4.49 & 4.70 & 3.20 \\
\hline $\mathbf{P}_{3}$ & 2.36 & 1.62 & 4.34 & 4.16 & 4.69 & 4.36 & 4.64 & 3.24 \\
\hline SEm \pm & 0.08 & 0.24 & 0.234 & 0.212 & 0.205 & 0.119 & 0.195 & 0.127 \\
\hline $\begin{array}{l}\mathrm{CD}(\mathrm{P}= \\
0.05 \%)\end{array}$ & NS & NS & NS & NS & 0.61 & NS & 0.58 & NS \\
\hline \multicolumn{9}{|l|}{ Interaction } \\
\hline SEm \pm & 0.13 & 0.41 & 0.405 & 0.367 & 0.355 & 0.205 & 0.355 & 0.221 \\
\hline $\begin{array}{l}\mathrm{CD}(\mathrm{P}= \\
0.05 \%)\end{array}$ & NS & NS & NS & NS & NS & NS & NS & NS \\
\hline
\end{tabular}


Table.3 Dry matter production $\left(\mathrm{kg} \mathrm{ha}^{-1}\right)$ of maize at different growth stages during kharif season

\begin{tabular}{|c|c|c|c|c|c|c|c|c|}
\hline \multirow{3}{*}{ Treatments } & \multicolumn{8}{|c|}{ Dry matter production } \\
\hline & \multicolumn{2}{|c|}{30 DAS } & \multicolumn{2}{|c|}{60 DAS } & \multicolumn{2}{|c|}{90 DAS } & \multicolumn{2}{|c|}{ At Harvest } \\
\hline & 2014 & 2015 & 2014 & 2015 & 2014 & 2015 & 2014 & 2015 \\
\hline \multicolumn{9}{|c|}{ Nitrogen levels $\left(\mathrm{kg} \mathrm{N} \mathrm{ha}^{-1}\right)$} \\
\hline $\mathrm{N}_{1}$ & 942 & 725 & 7823 & 6507 & 13882 & 16026 & 15093 & 21139 \\
\hline $\mathbf{N}_{2}$ & 1002 & 751 & 8756 & 7959 & 14793 & 16555 & 16320 & 21306 \\
\hline $\mathbf{N}_{3}$ & 1164 & 902 & 9392 & 8387 & 15508 & 17361 & 17521 & 22330 \\
\hline SEm \pm & 50.6 & 58.2 & 296.3 & 209.9 & 382.8 & 411.7 & 375.7 & 363.2 \\
\hline $\mathrm{CD}(\mathrm{P}=0.05 \%)$ & 152 & 175 & 888 & 629 & 1148 & 1235 & 1127 & 1082 \\
\hline \multicolumn{9}{|c|}{ Phosphorus levels $\left(\mathrm{kg} \mathrm{P}_{2} \mathrm{O}_{5}\right.$ ha $\left.^{-1}\right)$} \\
\hline $\mathbf{P}_{1}$ & 1019 & 805 & 7944 & 7715 & 14762 & 16255 & 15859 & 21659 \\
\hline $\mathbf{P}_{2}$ & 1105 & 889 & 8712 & 7994 & 14958 & 16445 & 16958 & 22701 \\
\hline $\mathbf{P}_{3}$ & 1061 & 837 & 8438 & 7744 & 15950 & 16325 & 17103 & 22116 \\
\hline SEm \pm & 50.6 & 58.2 & 296.3 & 209.9 & 382.8 & 411.7 & 375.7 & 834.3 \\
\hline $\mathrm{CD}(\mathrm{P}=0.05 \%)$ & NS & NS & NS & NS & 1148 & NS & 1127 & NS \\
\hline \multicolumn{9}{|l|}{ Interaction } \\
\hline SEm \pm & 87.7 & 102.5 & 513.3 & 363.6 & 663.1 & 713.0 & 650.7 & 1445.0 \\
\hline $\mathrm{CD}(\mathrm{P}=0.05 \%)$ & NS & NS & NS & NS & NS & NS & 1952 & NS \\
\hline
\end{tabular}

Interaction between $\mathrm{N}$ and $\mathrm{P}$ levels on dry matter production of maize during 2014

\begin{tabular}{|c|c|c|c|c|}
\hline & $\mathbf{P}_{\mathbf{1}}$ & $\mathbf{P}_{\mathbf{2}}$ & $\mathbf{P}_{\mathbf{3}}$ & Mean \\
\hline $\mathbf{N}_{\mathbf{1}}$ & 13236 & 16173 & 14968 & 14793 \\
\hline $\mathbf{N}_{\mathbf{2}}$ & 14163 & 16172 & 17725 & 16020 \\
\hline $\mathbf{N}_{\mathbf{3}}$ & 17178 & 18528 & 15957 & 17221 \\
\hline Mean & 14859 & 16958 & 16217 & \\
\hline
\end{tabular}

\begin{tabular}{|c|c|c|c|c|}
\hline \multicolumn{5}{|c|}{ Table.4 Grain and stover yield of maize as influenced by nitrogen and phosphorus levels } \\
during kharif season
\end{tabular}


Interaction between $\mathbf{N}$ and P levels on grain yield of maize during 2015

\begin{tabular}{|c|c|c|c|c|}
\hline & $\mathbf{P}_{\mathbf{1}}$ & $\mathbf{P}_{\mathbf{2}}$ & $\mathbf{P}_{\mathbf{3}}$ & Mean \\
\hline $\mathbf{N}_{\mathbf{1}}$ & 8071 & 8319 & 8120 & 8170 \\
\hline $\mathbf{N}_{\mathbf{2}}$ & 8986 & 9307 & 9055 & 9116 \\
\hline $\mathbf{N}_{\mathbf{3}}$ & 9087 & 9183 & 9169 & 9146 \\
\hline Mean & 8714 & 8936 & 8781 & \\
\hline
\end{tabular}

\section{Dry matter production}

Among the nitrogen levels tried, $300 \mathrm{~kg}\left(\mathrm{~N}_{3}\right)$ and $250 \mathrm{~kg} \mathrm{ha}^{-1}\left(\mathrm{~N}_{2}\right)$ produced significantly higher dry matter accumulation than that of $200 \mathrm{~kg} \mathrm{ha}^{-1}\left(\mathrm{~N}_{1}\right)$ (Table. 3). This indicated the positive effect of nitrogen in boosting the crop growth. Shivay and Singh (2000) observed that application of nitrogen increased plant height by increasing leaf size resulting in more and larger photosynthetic apparatus consequently influencing dry matter production. LAI and leaf greenness determine the capture and use of solar radiation by maize plant, there by affecting the conversion rate of available radiation to dry matter accumulation. These findings are in conformity with the results of Nsanzabaganwa et al., (2014) and Om et al., (2014).

Application of phosphorus at $60 \mathrm{~kg} \mathrm{ha}^{-1}\left(\mathrm{P}_{2}\right)$ resulted in higher dry matter, which was comparable to $80 \mathrm{~kg}^{\mathrm{ha}}{ }^{-1}\left(\mathrm{P}_{3}\right)$ and significantly superior to $40 \mathrm{~kg} \mathrm{ha}^{-1}\left(\mathrm{P}_{1}\right)$. It seems the reason is increase in leaf area, photosynthesis improvement resulting in higher dry matter. Araei and Mojaddam (2014) also recorded the highest dry weight and leaf area of maize by applying $60 \mathrm{~kg} \mathrm{P}$ ha ${ }^{1}$ over 0 and $90 \mathrm{~kg} \mathrm{P}_{2} \mathrm{O}_{5} \mathrm{ha}^{-1}$.

Interaction existed at the harvest stage of maize crop and the dry matter accumulation increased significantly by enhancing the fertility level up to $\mathrm{N}_{3} \mathrm{P}_{2}(300 \mathrm{~kg} \mathrm{~N}+60 \mathrm{~kg}$ $\mathrm{P}_{2} \mathrm{O}_{5} \mathrm{ha}^{-1}$ ), however this was significantly superior over $\mathrm{N}_{3} \mathrm{P}_{3}\left(300 \mathrm{~kg} \mathrm{~N}+80 \mathrm{~kg} \mathrm{P}_{2} \mathrm{O}_{5}\right.$ $\mathrm{ha}^{-1}$ ). Higher LAI paved the way for higher dry matter production. Similar observations were recorded by Gul et al., (2015) and Massey and Gaur (2016).

\section{Yield}

During the first year, application of $300 \mathrm{~kg} \mathrm{~N}$ $\mathrm{ha}^{-1}\left(\mathrm{~N}_{3}\right)$ resulted in higher grain yield, which was statistically superior to that of $250 \mathrm{~kg}$ $\left(\mathrm{N}_{2}\right)$ and $200 \mathrm{~kg} \mathrm{~N} \mathrm{ha}^{-1}\left(\mathrm{~N}_{1}\right)$. The lowest grain yield was associated with $200 \mathrm{~kg} \mathrm{~N} \mathrm{ha}^{-1}\left(\mathrm{~N}_{1}\right)$. During the second year nitrogen applied at $300 \mathrm{~kg} \mathrm{ha}^{-1}\left(\mathrm{~N}_{3}\right)$ resulted in highest grain yield, which was statistically on par with that of $250 \mathrm{~kg} \mathrm{~N} \mathrm{ha}^{-1}\left(\mathrm{~N}_{2}\right)$. The lowest grain yield was associated with $200 \mathrm{~kg} \mathrm{~N} \mathrm{ha}{ }^{-1}\left(\mathrm{~N}_{1}\right)$ (Table. 4). This might be due to favourable effect at higher nitrogen level leading to better crop growth and increase in yield attributes which was reflected in kernel yield of maize. In physiological terms, the grain yield of maize was largely governed by source and sink relationships as it is directly related to nitrogen. These results are in accordance with the findings of Nsanzabaganwa et al., (2014), Om et al., (2014) and Thimmappa et al., (2014).

Maize supplied with $60 \mathrm{~kg} \mathrm{P}_{2} \mathrm{O}_{5} \mathrm{ha}^{-1}\left(\mathrm{P}_{2}\right)$ resulted in higher grain yield, which was however statistically on par with $80 \mathrm{~kg} \mathrm{P}_{2} \mathrm{O}_{5}$ $\mathrm{ha}^{-1}\left(\mathrm{P}_{3}\right)$. Significantly lowest grain yield was obtained with $40 \mathrm{~kg} \mathrm{P}_{2} \mathrm{O}_{5} \mathrm{ha}^{-1}\left(\mathrm{P}_{1}\right)$ in the first year. Similar trend was observed during the second year but all the three phosphorus levels recorded statistically on par values of grain yield. 
Grain yield of maize increased significantly up to $60 \mathrm{~kg} \mathrm{P}_{2} \mathrm{O}_{5} \mathrm{ha}^{-1}$. Further increase in $\mathrm{P}$ from 60 to $80 \mathrm{~kg} \mathrm{P}_{2} \mathrm{O}_{5} \mathrm{ha}^{-1}$, failed to record statistical significance. Increase in grain yield up to certain level of phosphorus was directly related to the vegetative and reproductive growth phases of the crop and attributes to complex phenomenon of phosphorus utilization in plant metabolism. Similar results were obtained by Araei and Mojaddam (2014) and Nsanzabaganwa et al., (2014).

Highest grain yield of maize was recorded with $\mathrm{N}_{2} \mathrm{P}_{2}\left(250 \mathrm{~kg} \mathrm{~N}+60 \mathrm{~kg} \mathrm{P}_{2} \mathrm{O}_{5}\right.$ ha $\left.^{-1}\right)$ which was statistically superior over lower levels of $\mathrm{N}$ and $\mathrm{P}$, while on par with the higher levels. The balanced nitrogen and phosphorus levels might have helped in efficient absorption and utilization of other required plant nutrients which ultimately increased the grain yield. Similar results were obtained by Jaliya et al., (2008) and Abera et al., (2009).

Stover yield of maize increased significantly with increase in nitrogen levels from 200 to $300 \mathrm{~kg} \mathrm{~N} \mathrm{ha}{ }^{-1}$. Increased stover yield with increase in nitrogen level could be attributed to adequate nutrient supply, which in turn improved growth parameters like plant height, leaf area index and dry matter production which resulted in higher stover yield. These results are agreement with the findings of $\mathrm{Om}$ et al., (2014).

Stover yield of maize increased significantly up to $60 \mathrm{~kg} \mathrm{P}_{2} \mathrm{O}_{5} \mathrm{ha}^{-1}$. Further increase in $\mathrm{P}$ from 60 to $80 \mathrm{~kg} \mathrm{P}_{2} \mathrm{O}_{5} \mathrm{ha}^{-1}$, decreased the stover yield. Higher straw yield at medium phosphorus level could be attributed to adequate and balanced nutrient supply over higher and lower levels. Similar results were obtained by Araei and Mojaddam (2014) and Nsanzabaganwa et al., (2014).

Combination of $250 \mathrm{~kg} \mathrm{~N}$ and $60 \mathrm{~kg} \mathrm{P}_{2} \mathrm{O}_{5} \mathrm{ha}^{-1}$ was found to be advantageous in getting the higher values of growth parameters and the yield of maize during kharif season.

\section{References}

Abera, T., Feyisa, D and Friesen, D. K. 2009. Effects of Crop Rotation and N-P Fertilizer Rate on Grain Yield and Related Characteristics of Maize and Soil Fertility at Bako, Western Oromia, Ethiopia. East African Journal of Sciences. 3 (1): 70-79.

Araei, M and Mojaddam, M. 2014. The effect of different levels of phosphorus from triple super phosphate chemical fertilizers and biological phosphate fertilizer (fertile 2) on physiological growth parameters of corn (sc704) in Ahvaz weather conditions. International Journal of Plant, Animal and Environmental Sciences. 4: 625-632.

Ayoola, O. T. and Adeniyan, O. N. 2006. Influence of poultry manure on yield and yield components of crops under different cropping systems in South west Nigeria. African Journal of Biotechnology. 5:1386-1392.

Baffoe, M. J. N. 2014. Effect of different rates of nitrogen and phosphorus fertilizer on maize grain protein content. M.Sc. thesis submitted to the University of Ghana Legon, Accra, Ghana.

Dawadi, D. R and Sah, S. K. 2012. Growth and yield of hybrid maize (Zea mays L.) in relation to planting density and nitrogen levels during winter season in Nepal. Tropical Agricultural Research. 23 (3): 218-227.

FAO. (2007). Food and Agriculture Organisation yearbook Volume 60 .

Gemechu, G. A. 2011. Influence of nitrogen and phosphorus fertilizers on seed yield and quality of maize (Zea mays L.) at Bedele, South-Western Ethiopia. M. Sc thesis submitted to the Department of Plant Sciences, School of Graduate 
Studies, Haramaya University, Ethiopia.

Gul, S., Khan, M. H., Khanday, B. A and Sabeena Nabi. 2015. Effect of sowing methods and NPK levels on growth and yield of rainfed maize (Zea mays L.) Hindawi Publishing Corporation, Scientifica. 1-6.

Jaliya, A. M., Falaki, A. M., Mahmud, M Sani, Y. A. 2008. Effects of sowing date and NPK fertilizer rate on yield and yield components of quality protein maize (Zea mays L.). Journal of Agriculture and Biological Sciences. 2:23-29.

Massey, J. X and Gaur, B. L. 2006. Effect of plant population and fertility levels on growth and NPK uptake by sweet corn (Zea mays L.) cultivars. Annals of Agricultural Research (New series). 27 (4): 365-368.

Nsanzabaganwa, E., Das, T. K and Rana, D. S. 2014. Nitrogen and phosphorus effects on the growth, phenology, heat and nutrients accumulation and yield of winter maize (Zea mays) in Western Indo-Gangetic Plains. Indian Journal of Agricultural Sciences. 84 (5): 661-664.

Om, H., Singh, S. P., Singh, J. K., Singh, R. N., Ansari, M. A., Meena, R. L and
Yadav, B. 2014. Productivity, nitrogen balance and economics of winter maize (Zea mays) as influenced by QPM cultivars and nitrogen levels. Indian Journal of Agricultural Sciences. 84 (2): 306-308.

Saeed, I. M., Abbasi, R and Kazim, M. 2001. Response of maize (Zea mays) to nitrogen and phosphorus fertilization under agro-climatic condition of Rawalokol, Jammu and Kaslim and Kashmir. Pakistan Journal of Biological Sciences. 4: 949-952.

Shivay, Y. S and Singh, R. P. 2000. Growth, yield attributes, yield and nutrient uptake of maize (Zea mays L.) as influenced by cropping systems and nitrogen levels. Annals of Agricultural Research. 21 (4): 494-498.

Sridhar, M. K. C and Adeoye, G. O. 2003. Organo-mineral fertilizer from urban wastes. The Field. 68:91-111.

Thimmappa, V., Reddy, M. S., Reddy, U. V. B and Reddy, S. T. 2014. Effect of nitrogen levels and plant densities on growth parameters, yield attributes and yield of kharif maize (Zea mays L.). Crop Research. 47 (1, 2 \& 3): 29-32.

\section{How to cite this article:}

Vijaya Bhaskar Reddy, U., G. Prabhakara Reddy, M. Srinivasa Reddy and Kavitha, P. 2018. Effect of Different Nitrogen and Phosphorus Levels on Growth and Yield of Maize during Kharif Season. Int.J.Curr.Microbiol.App.Sci. 7(1): 3548-3555.

doi: https://doi.org/10.20546/ijcmas.2018.701.416 